\title{
The Colonial Aspects of International Environmental Law: Treaties as Promoters of Continuous Structural Violence
}

\author{
Douglas de Castro*
}

DOI: $10.21827 / 5 \mathrm{a} 6 \mathrm{af9} 946 \mathrm{c} 2 \mathrm{ff}$

\author{
Keywords \\ IMPERIALISM; STRUCTURAL VIOLENCE; INTERNATIONAL ENVIRON- \\ MENTAL LAW; TWAIL; METANARRATIVES
}

\begin{abstract}
The formation of international institutions in the twentieth century occurs under a scenario marked by the rule of colonialism and imperialism. Thus, instead of reducing inequalities in the world system, international institutions reproduce a prevalent logic of material and subjective discrimination based on a colonialist ideology marked by violence, which is communicated in a certain way so that it can justify its importance and legitimacy. The colonial violence is perpetuated under the form of symbolic violence manifested in the language that imposes a universal meaning and systemic violence that manifests itself in the 'perfect' functioning of the world economic and political system as the ultimate form of development. One of the perverse and subtle dimensions of this violence is observed in the emergence of the International Environmental Law in terms of metanarratives that exclude minorities and perceptions other than the ones propagated by international institutions. The main objective of this article is to identify the dynamics in the formation of environmental treaties leading to standard results of discursive practices that feed the process of dependence and legitimation marked by colonial ruling and structural violence. The methodological approach relies on the critical theory tenets to expose the non-emancipatory features of current International Environmental Law. For that matter, this article applies the socio-legal approach to environmental treaties that consists of the analysis of text (law), subtext (the moral aspects of the law - deep or implicit meanings), and context (the undeniable connection between law and reality) in the search of empirical evidence. This task is performed using the computer assisted qualitative data analysis software (CADQAS) called ATLAS.ti.
\end{abstract}

\section{Introduction}

There is a fundamental issue in investigating social reality ${ }^{1}$ - there are objective facts in the real world that are fact only by human agreement, which Searle named institutional facts. ${ }^{2}$ Although dealing with a complex hoard of variables involving natural process, and to a certain point relying on scientific knowledge, International Environmental Law

Post-Doc Researcher at the São Paulo School of Law (FGV). PNPD-CNPQ Research Grant. PhD in Political Sciences and Master in International Law (São Paulo University). LLM in International Law by Brigham Young University (United States). Professor of International Law and International Relations and Senior Researcher of the CNPQ Group Research "The Critics and the Law" (UNIP-São Paulo). My sincere thanks to CNPQ for funding my research; São Paulo School of Law-FGV for institutional support; and my friend Michelle Ratton Sanchez Badin for continuous encouragement.

Searle, JR, The Construction of Social Reality, Free Press (1997).

2 According to Ludwig Wittgenstein, 1.1 of the Tractatus Logico-Philosophicus: Die Welt ist durch die Tatsachen bestimmt und dadurch, dass es alle Tatsachen sind (The world is determined by the facts, and by these being all the facts). In Wittgenstein, L, Tractatus Logico-Philosophicus Logisch-philosophische Abhandlung, Kegan Paul 1922, (accessed on 7 September 2017). 
(IEL) is an institutional fact that reflects the construction of political consensus among the basic units in the international system - the States.

The prevalent discourse of the states is marked by the scientific rationality and the search for universality, which promotes the false reality that whatever is enacted by way of the historical sources of law, as posed by Article 38 of the International Court of Justice Statute, is good for humanity. Thus, any non-compliance with its tenets constitutes a violation of International Law and subjects the violator to sanctions (whatever sanction means in International Law, some might say.)

IEL is the part of the totalizing and non-temporal visions of history that prescribes political and ethical rules for all humanity based on the modern West epistemology. Modern scientific discourse is based on the premise that science is a self-referent activity that has the purpose of breaking the ties with tradition and common sense, thus, contributing to the moral and spiritual development of humanity.

The existing discourses considering complete views of history and politics are known as metanarratives. The social reality in the 21 st century is marked by an increasing degree of globalization and technological development that generates a strong tension with the metanarratives embodied in IEL. As a result, new language and concepts scape the theoretical provisions of the modernist project, which crumbles its legitimacy, thus, questioning the notion of order and/or the 'normal' functioning of the international system. This fact points to the contradiction between the discourse of universality and the empirical dimension marked by non-emancipatory and nonliberating features that exacerbates the existing tensions due to inequality, underdevelopment, hunger, and environmental challenges, just to name a few. ${ }^{3}$

Although there is a massive consensus concerning the importance of preserving and protecting the environment for the present and future generations, its epistemology and ontology are relegated to a second tier of concern due to the fact that political rhetoric of fear is introduced as the natural justification for states to apply extreme measures as pleased. ${ }^{4}$

Mapping the history of the global institutions and law concerning the environment, we observe that concerns about the environment started during the colonization period of history during which natural resources were regulated by the great European powers for the purpose of continuous use. For instance, the 1900 International Convention on the Conservation of Wild Animals, Birds and Fish in Africa negotiated by hunters is considered the precursor of the Convention on International Trade in Endangered Species, which mimics the calibration of destruction of its colonial predecessor. Other historical evidence is the initial attempt to contain deforestation in the colonies during the 1700s that still persist in our days in the form of the climate change regime. While the international community recognizes the urgency of taking actions for human survival, a disconcerting apathy due to the inaction of countries is the most distinguishable trace. ${ }^{5}$

Nicholls, P, "Divergences: Modernism, postmodernism, Jameson and Lyotard" 33(3) Critical Quarterly (1991) 1, <onlinelibrary.wiley.com/doi/10.1111/j.1467-8705.1991.tb00958.x/epdf> (accessed on 19 November 2017).

4 Bauman, R, "Changes in the Appalachian Wage Gap, 1970 to 2000" 37(3) Growth and Change (2006) 416, <onlinelibrary.wiley.com/doi/10.1111/j.1468-2257.2006.00330.x/epdf>; Weiss, EB, " In Fairness To Future Generations and Sustainable Development" 8(1) American University International Law Review (1992) 19 <digitalcommons.wcl.american.edu/cgi/viewcontent.cgi?article=1498\&context= auilr> (accessed on 12 December 2017).

Grove, RH, Green Imperialism: Colonial Expansion, Tropical Island Edens and the Origins of Environmentalism, 1600-1860, Cambridge University Press (1996,), 45. 
Therefore, this paper intends to cast some light on the structures of IEL to reveal the hidden structures of imperialism in dealing with the environment. To do so, this article builds a theoretical framework composed by feminist theory (FT), which should be tested in the international climate change regime in searching for minimal empirical evidences. $^{6}$

The central argument of this paper is that there is a 'moral grammar' in the climate change regime that excludes the participation of women as an imperialist practice. $^{7}$ The figure below is representative of the quantitative discrepancy in terms of participation of women (Ms) versus men (Mr) in the climate regime, which for the purposes of our work consists of the visible dimension of the excluding nature of IEL. The 'word cloud' is made using treaties dealing with climate change from the 1991-2015 interval, which were randomly selected (listed in Figure 2).

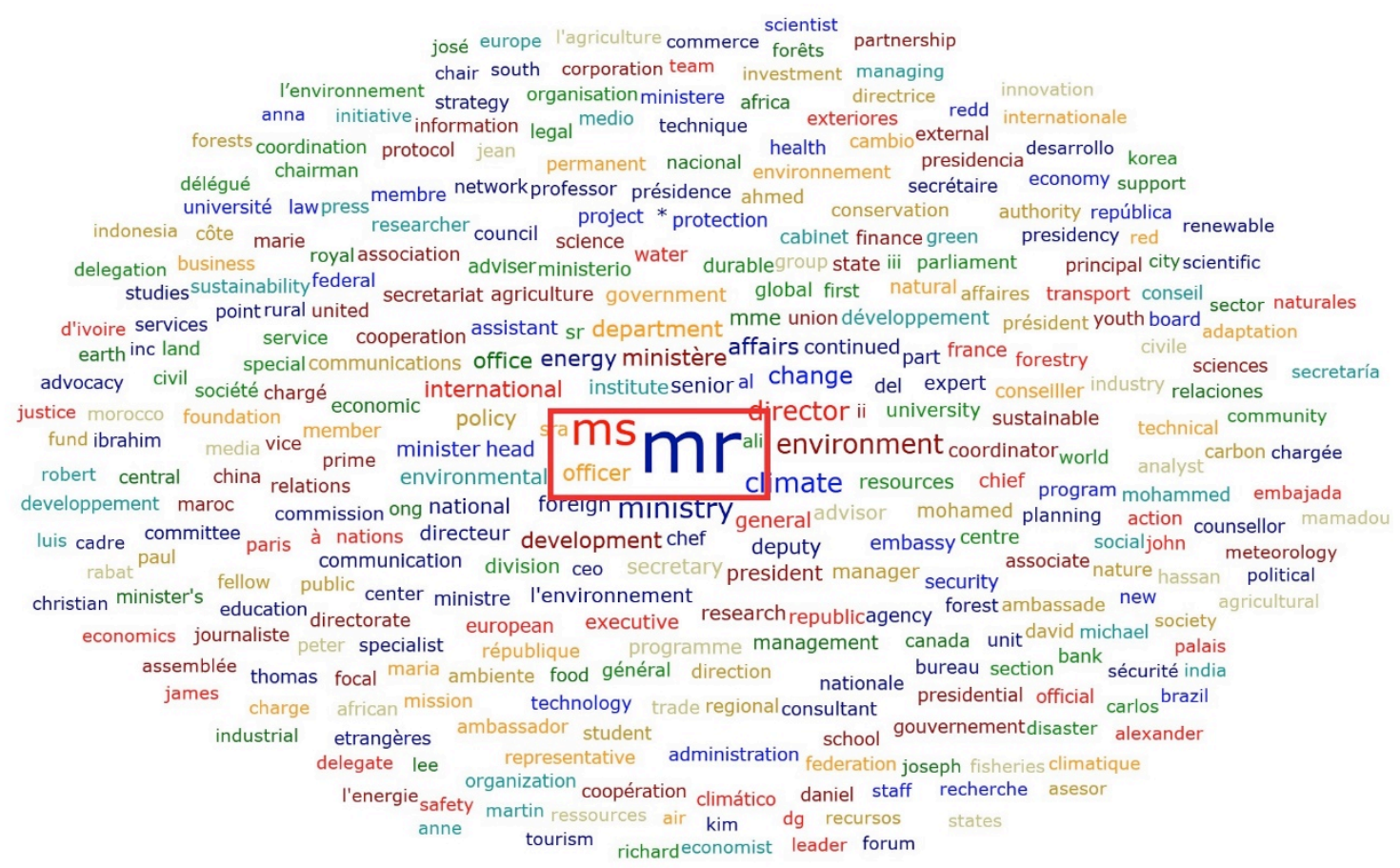

Figure 1

Source: The Author ${ }^{8}$

6 More about feminist theory is explained in the next section; however, I should mention that from the existing strings of critical theory, I have chosen feminist theory due to its epistemological spectrum that might be appropriated by other marginalized people, especially considering the application of the intersectionality concept (Davis, K, "Intersectionality as buzzword: A sociology of science perspective on what makes a feminist theory successful", Feminist Theory (2008), 9(1), 67-85).

7 Zurn, C, Axel Honneth, John Wiley \& Sons, 2015.

8 The word cloud has been prepared by the author using a computer assisted qualitative data analysis software (CADQAS) called ATLAS.ti. The documents used for this analysis were: Geneva, 1991 section 2; Nairobi, 1991 section 3; Geneva, 1991 section 4; New York, 1991 section 5; New York, 1991 section 5II; Geneva, 1992 section 6; New York, 1993, section 6; Geneva, 1993 section 8; Kyoto, 1997, section 3; Paris, 2015 section 20; and Marrakesh, 2016, section 22. These are the randomly chosen preparatory meetings for the conclusion of the United Nations Framework Conference on Climate Change (1992), Kyoto Protocol (1998), and Paris Agreement (2015). The provisional lists of participants can be found at <unfccc.int/documentation/documents/items/3595.php. > (accessed on 18 November 2017). 
The quantitative dimension is not enough to provide evidence for our argument. The research, therefore, adopts the procedure of content analysis of selected IEL treaties to identify the substantial and relational social history that shapes the moral grammar of gender oppression as one of the axes of a larger context of imperial power, that is, unveiling the hidden structures of power in the IEL's lexicon. ${ }^{9}$ To conduct a more rigorous content analysis, the methodological path should follow the socio-legal approach $^{10}$ as well, which consists of the text analysis (law), subtext (the moral aspects of the law - deep or implicit meanings), and context (the undeniable connection between law and reality). ${ }^{11}$

The empirical objective is identifying in the IEL selected documents the excluding language of metanarratives that contradict the emancipatory concepts used by FT such as hope, creativity, resilience, persistence, and solidarity. ${ }^{12}$ This task will be conducted using a computer assisted qualitative data analysis software (CADQAS) called ATLAS.ti. ${ }^{13}$

\section{The Visible and Less Visible Dimensions of Domination in International Environmental Law}

In the introduction of this paper, we have already pointed out the existence of a visible dimension in the international system related to the lack of participation of women. The trend observed in the climate change regime might be observed in other fields of International Law as this discriminatory feature is not exclusive to the IEL field. Thus, this part of the article presents the theoretical and empirical dimensions, conditions and encounters of IEL with FT to produce implications for other areas of International Law.

9 See Emirbayer, M, "Manifesto for a Relational Sociology",103(2) American Journal of Sociology (1997), 281-317, at <jstor.org/stable/10.1086/231209>, (accessed on 18 November 2017); (Krippendorff, K, Content Analysis: An Introduction to its Methodology $3^{\text {rd }}$ ed, Sage (2012); Bardin, S, "Investigating Transport of Dust Particles in Plasmas" 51(2-3) Contributions to Plasma Physics (2011).

10 Firstly, what is approached? Socio-legal approaches consider not only legal texts, but also the contexts in which they are formed, destroyed, used, abused, avoided and so on; and sometimes their subtexts. Secondly, how is socio-legal thinking and practice undertaken? It is interdisciplinary, drawing (analytically) on the concepts and relationships and (empirically) on the facts and methods of the social sciences, and sometimes the humanities. Thirdly, why is socio-legal thinking and practice undertaken? Socio-legal approaches to international economic law aim to understand legal texts, contexts and subtexts, sometimes for the objective purpose of achieving clarity, sometimes with a view to changing them, Perry-Kessaris, AP, Socio-Legal Approaches to International Economic Law: Text, Context, Subtext (Routledge 2013) 6.

11 It is an essential task of any complete theory of society to investigate not just social institutions and practices, but also the beliefs agents have about their society - to investigate not just the social reality in the narrowest sense, but the social knowledge which is part of that reality (Geuss, R, The Idea of a Critical Theory: Habermas and the Frankfurt School, (Cambridge University Press 1981), 56; Perry-Kessaris, A, What Does it Mean to Take a Socio-Legal Approach to International Economic Law? (Routledge 2012).

12 Otto, D, "Feminist Approaches to International Law" In Orford, A and Hoffmann, F, The Oxford Handbook of the Theory of International Law (Oxford University Press 2016).

13 In expressly stating the methodology used in this article, my intent is to point out the urgent need for researchers working on with postcolonial theory to build epistemological and ontological foundations to avoid the criticism of the lack of it and the pamphleteer nature of the TWAIL studies. 


\section{A. The Visible Dimension of Domination}

The evidence of the visible dimension becomes a serious issue in IEL, considering its alleged progressive nature that, among other things, incorporates non-state agents such as non-governmental organisations (NGOs) as important actors in the formation of international norms and institutions related to the environment. ${ }^{14}$

In Figure 2 below, the data behind the graphic represents the participation of men and women as representatives of States, Intergovernmental Organisations and NonGovernmental Organisations. In Figure 3, we isolated the participation of men and women as representatives of NGOs. As observed by comparing the graphics, the gap between the men and women's participation as representatives of NGOs is larger than the consolidated graphic. It is interesting to note that NGOs have emerged in the context of the failure of the State's performance in providing public goods to society, including gender equality in politics. Thus, the general expectation is that NGOs constitute spaces of plurality and participation, which seems not to be the case in the climate change regime. $^{15}$

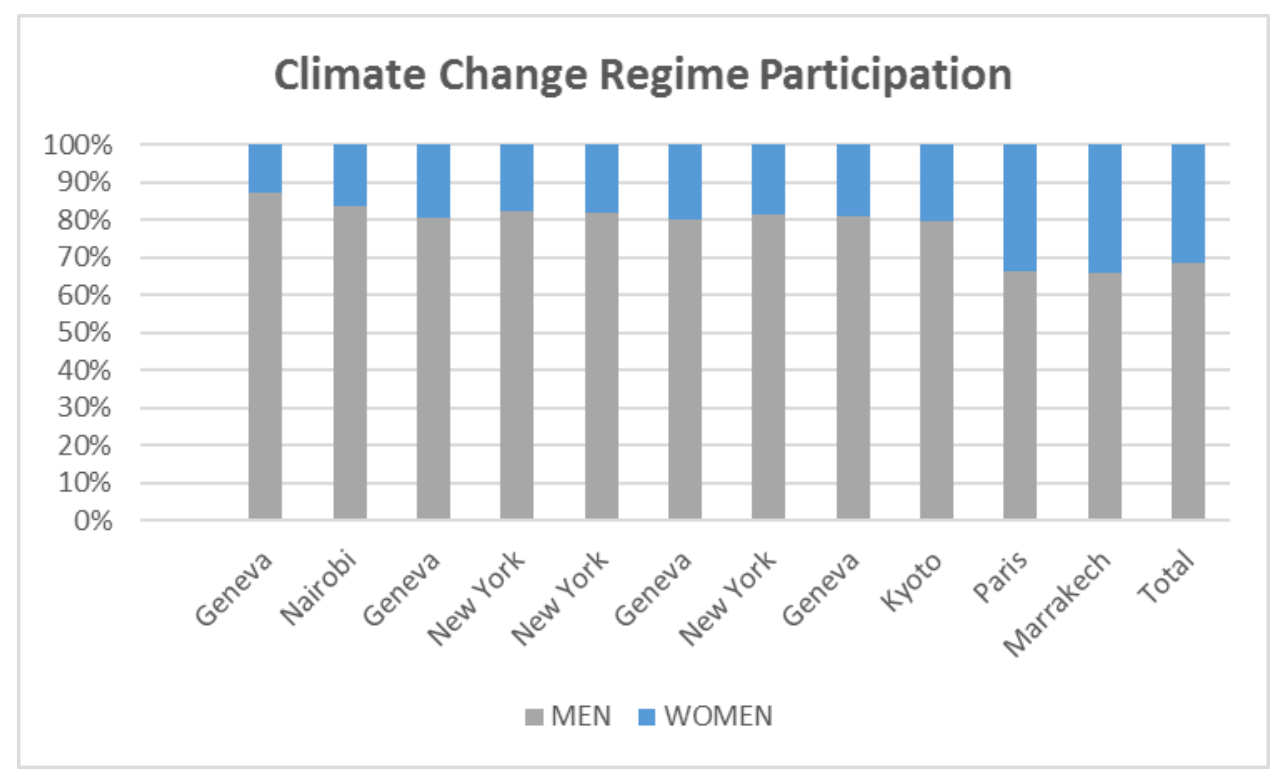

Figure 2

14 Charnovitz, S, "Particapation of Nongovernmental Organizations in the World Trade Organization (Participation of Nongovernmental Parties in the World Trade Organization)" 17(1) University of Pennsylvania Journal of International law (1996) 331, <scholarship.law.upenn.edu/jil/vol17/iss1/11/> ; Yamin, F, "NGOs and International Environmental Law: A Critical Evaluation of their Roles and Responsibilities" 10(2) Review of European, Comparative and International Environmental Law (2001) 149, <onlinelibrary.wiley.com/doi/10.1111/1467-9388.00271/abstract>, (accessed on 19 November 2017).

15 As one of the purposes of this work is providing insights for the development of research agendas, this phenomenon is worth collecting data and analyzing variables for the non-participation of women as expected. To see a complete inventory on the theories for conceptualizing NGO's, we suggest Sama, TB, "Conceptualizing Non-Governmental: Still Searching for Conceptual Clarity", 3(1) Journal of Social and Psychological Sciences (2010), 32; (Kelly, BC, "Some Aspects of Measurement Error in Linear Regression of Astronomical Data" 665 The Astrophysical Journal (2007), <iopscience.iop.org/article/10.1086/519947/pdf> (accessed on 19 November 2017). 


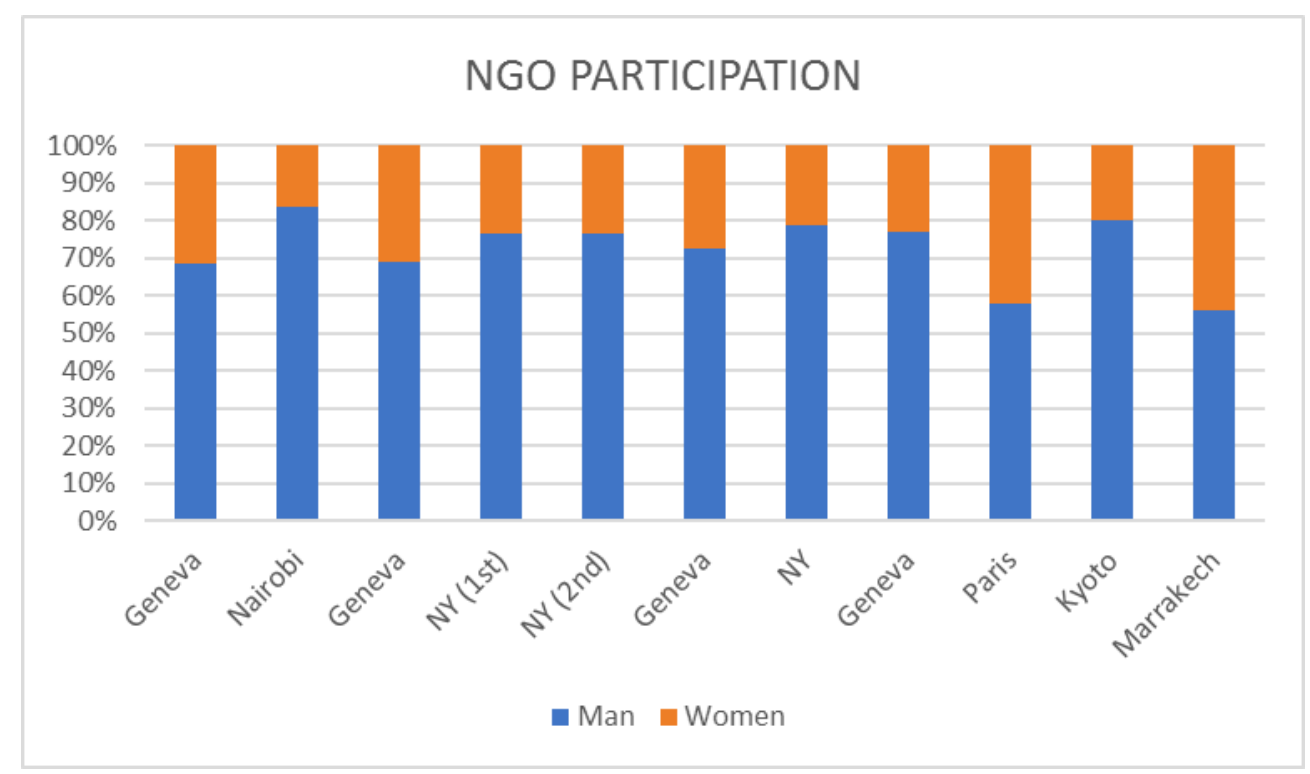

Figure 3

Thus, this simple quantitative analysis provides empirical indications of the gap which reflects how IEL grasps, or fails to do so, the social demands in society and, more importantly, how it affects those who need the most extension of protection of law. As such, according to Sweetman, this discrepancy between women and men participation affects directly the concept of climate justice:

The United Nations is formally committed to gender mainstreaming in all policies and programmes, and that should include policy-making processes relating to climate change. Yet gender aspects are rarely addressed in climate-change policy, either at the national or at the international levels. Reasons include gaps in gender-sensitive data and knowledge about the links between gender justice and climate change; and the lack of participation of women and gender experts in climate-related negotiations...In some European countries, women have been more supportive of their governments' climate-protection policies than men, and would also be more supportive of more ambitious reduction goals, basically expecting their countries and the European Union to take a leadership role. The international climate negotiations are in dire need of such support. ${ }^{16}$

The analysis of the visible dimension of discrimination in IEL leads us to a more elusive form of discrimination incorporated into the language of IEL under the flags of development, sustainable development, universality, among other common terms, known as metanarratives. Thus, in the next part of the article, we investigate the less visible form of domination that permeates IEL.

16 Sweetman, P, "Revealing habitus, illuminating practice: Bourdieu, photography and visual methods" 57(3) The Sociological Review155 (2009) 491, <onlinelibrary.wiley.com/doi/10.1111/j.1467-954X.2009. 01851.x/abstract> (accessed on 19 November 2017). 


\section{B. The Less Visible Dimension of Domination i. Conceptualizing Domination}

Our starting point in unveiling the less visible dimension of domination is presenting the general tenets of the concept of imperialism. ${ }^{17}$ Young presents the concept of imperialism in such a way that is less problematic in terms of contrasting it with colonialism. For some both concepts are wrongfully interchangeable:

'The term 'empire' has been widely used for many centuries without, however, necessarily signifying 'imperialism'. Here a basic difference emerges between an empire that was bureaucratically controlled by a government from the centre, and which was developed for ideological as well as financial reasons, a structure that can be called imperialism, and an empire that was developed for settlement by individual communities or for commercial purposes by a trading company, a structure that can be called colonial. ${ }^{18}$

Therefore, the conceptualization of imperialism is based on the exercise of power

'[...] either through direct conquest or (latterly) through political and economic influence that effectively amounts to a similar form of domination. Both involve the practice of power through facilitating institutions and ideologies'. ${ }^{19}$

The key-point in this discussion involves the notion of spreading institutions and ideologies that propagate social and political structures as a form of domination and discrimination. Of course, the economic dimension is present in this notion of imperialism. However, note that it is not a simply colonial venture we are referring to but one larger in scope and purpose, which demands a high level of bureaucratic control that dictates the rules and conditions of participation of minorities. ${ }^{20}$ This is what Skolimowski refers to when stating, 'The present physical interpretation of power is but a

17 The concept of imperialism and its relationship with the concept of colonialism is complex and controversial. For a deeper analysis on this matter: Young, RJ.C, Postcolonialism: An Historical Introduction (Wiley-Blackwell 2001).

18 Niemi, L and Young, L "When and Why We See Victims as Responsible - The Impact of Ideology on Attitudes Toward Victims" 42(9) Personality and Social Psychology Bulletin (2016) 1227 p, 16, <journals.sagepub.com/doi/abs/10.1177/0146167216653933> (accessed on 19 November 2017).

19 Interesting to note that even gender discourse might be used as a tool for domination as the following passage suggests: Positing the nation as Imperial Mother can be viewed, on the one hand, as a reworking of France's imperial identity, but also as the expression of concerns relating to the future of the French race, sexual morals, and the position of France in the colonized territories. The feminized version of imperial identity functioned to some degree not only as an assertion of plenitude toward the colonized, but also as a symbol of the hope of a national regeneration abroad, see Fishcher-Tine, $\mathrm{H}$ and Gehrmann, S, Empires and Boundaries: Race, Class, and Gender in Colonial Settings, (Routledge 2008). See also Hobson, JA, Imperialism: A Study (Andesite Press 2015); Niemi and Young, Ibid, 27.

20 The speech made by Lord Cruzon at the Byculla Claub in 1905 is representative of this logic:

To fight for the right, to abhor the imperfect, the unjust or the mean, to swerve neither to the right hand nor to the left, to care nothing for flattery or applause or odium or abuse it is so easy to have any of them in India never to let your enthusiasm be soured or your courage grow dim, but to remember that the Almighty has placed your hand on the greatest of his ploughs, in whose furrow the nations of the future are germinating and taking shape, to drive the blade a little. Internet Archive, Full text of "Lord Curzon's farewell to India. Being speeches delivered as viceroy \& governor-general of India. During Sept.-Nouv. 1905", <archive.org/stream/lordcurzonsfarew00curzrich/lordcurzonsfarew00curzrich_djvu.txt> (accessed on 18 November 2017). 
manifestation of the larger process of turning everything into an object, generally an object of manipulation. ${ }^{21}$

Thus, spreading institutions and ideologies as forms of domination and discrimination is closely related to violence as conceptualized by Zizek. ${ }^{22}$ The signals of violence that the human race receives are associated with crime and terror, civil unrest and international conflict. Thus, it is a type of violence that is perceived upfront and perpetrated by identified agents. According to Zizek, we should take a step back to perceive the context in which these outbursts of violence happen, so we might identify the violence that sustains our efforts to fight violence and promote tolerance (such a paradox one might say) ${ }^{23}$

The visible form of violence is called subjective, which brings undesired perturbation to the normal state of affairs of a given society and institutions. On the other hand, objective violence is a refined kind of violence that is imposed to define the parameters of the normal, which systemic and symbolic violence are part of ${ }^{24}$ For Zizek, symbolic violence is the one embodied in the language and forms that directs to domination or imposes a certain universal meaning, and systemic violence is related to the smooth functioning of the dominating economic and political institutions.

In this sense, material conditions within international institutions are fundamental to the formation of the normal state, alongside with the construction of this state through a set of meanings so powerful that it becomes the ideology that shapes social reality within the boundaries of the dominating group. ${ }^{25}$

Therefore, challenging the climate change regime as it is institutionalized nowadays is a perturbation of what is institutionalized as normal for the international community. In defying a system that is prevalently masculine or that excludes Third World Countries from the debate of what is desired in terms of sustainable development disrupts the normal order of things as institutionalized in the world system, which is embodied in the process of the decolonization of countries. ${ }^{26}$ This is what Chimni refers to:

There is the old idea, which has withstood the passage of time, that dominant social forces in society maintain their domination not through the use of force but through having their worldview accepted as natural by those over whom domination is exercised. Force is only used when absolutely necessary, either to subdue a challenge or to demoralize those social forces aspiring to question the 'natural' order of things. ${ }^{27}$

21 Skolimowski, H, "Power and Myth" 9(1) Alternatives (1983), 25, http://journals.sagepub.com/doi/10.1177/030437548300900102>, (accessed on 19 November 2017), p 1.

22 Zizek, S, Violence: Six Sideways Reflections (Profile Books 2008).

23 Ibid.

24 Ibid.

25 This is what Habermas calls forms of technocratic management. See Habermas, J, The Structural Transformation of the Public Sphere: An Inquiry into a Category of Bourgeois Society, 6th edition (The MIT Press 1991); Eagleton, T, The Meaning of Life, (Oxford University Press 2007).

26 Wallerstein, I, World-Systems Analysis: An Introduction (Duke University Press 2004).

27 Chimni, BS, "The World Trade Organisation, Democracy and Development: A View from the South" 40(1) Journal of World Trade (2006) 5, <kluwerlawonline.com/abstract.php? area $=$ Journals\&id $=$ TRAD2006002 $>$ (accessed on 19 November 2017). 
Upon the prevalent logic of systemic and symbolic violence that permeates international institutions, ${ }^{28}$ the question posed by Spivak remains unanswered - can the subaltern speak ${ }^{29}$ Rather, the question should be how will the subaltern speak? The second question is important as international institutions are excluded due to the need the West has in keeping itself as the subject of higher social relations, and thus, the constructor of the subaltern through the imposition of politics, economy, law, culture and so forth as universal truths. ${ }^{30}$ In addition to being a construction of the subject, referring to climate change, the relationship with nature is historically and politically marked by the subjectobject logic that reflects the 'right' or enticement of exploring natural resources. ${ }^{31}$

In terms of providing the basis for the rationale and legitimation of this logic, International Law is an important venue. Theories of International Law have focused traditionally on keeping the status of the state as the privileged subject of theorization, mainly to make sure that sovereignty, as principle and practice, remains unchallenged or at least in place to exclude undesired disturbances to the normal functioning of the system. In addition, theories in International Relations, especially realism, are keen to secure this rationale by pointing to an international structure marked by anarchy with the state as the main and unitary actor due to its sovereignty. ${ }^{32}$ To Mattei, the process of construction of this logic is based on the following process:

The rhetorical artifice used in the process of curbing deviant behaviour and claiming, as universal and inevitable, the Western modalities of social organisation and economic development centred on individualism and social fragmentation, is usually an explicitly juridical concept: "international human rights." In the interests of these rights, a doctrine of "limited sovereignty" has threatened the traditional nature of international law as a decentralized system based on territoriality and has advocated the need for decentralization in order to make it more like any other Western national legal system. (Translated by the Author). ${ }^{33}$

To that end, environmental phenomena tend to create stress and generate heat in the system by disregarding states' boundaries and thus sovereignty, the growing dependency of states on scientific and epistemic communities to explain changes and negative impacts of anthropic activities to the environment, and the increasing participation of

28 In this article, we should not present a complete inventory of the debate around the general claim made that international institutions reproduce colonial structures of domination. See Chimni, BS, "International Institutions Today: An Imperial Global State in the Making." 5(1) European Journal of International Law, 1 , <://doi.org/10.1093/ejil/15.1.> (accessed on 18 November 2017); Magdoff, H, and Foster, JB, Imperialism Without Colonies (Monthly Review Press 2003); Magdoff, H, and Foster, JB, Imperialism Without Colonies (Monthly Review Press 2003).

29 This question refers to and is the title of the books: Spivak, GC, Can the Subaltern speak, (Turia + Kant 2007).

30 For the debate about civilizational formation and conceptualization we recommend reading: GONG, G W, "The Standard of "Civilization" in International Society" (Oxford University Press 1984); Spivak Ibid; Said, EW, Orientalism (Vintage Books 1979).

31 Chakrabarty, B and Zhang, G "Credit Contagion Channels: Market Microstructure Evidence from Lehman Brothers' Bankruptcy" 41(2) Financial Review (2012) 320, <onlinelibrary.wiley.com/doi/10.1111/j.1755-053X.2012. 01194.x/abstract>, (accessed on 19 November 2017).

32 For a deeper debate on the formation of theories in International Law see Oxford, Orford A and Hoffmann, F, The Oxford Handbook of the Theory of International Law (Oxford University Press 2016).

33 See also, Anghie, A et al, Imperialismo y Derecho internacional (Siglo del Hombre 2016); Mattei, U and Nader, L, Pillaging/268, WMF Martins Fontes (2013). 
civil society, mainly NGOs in the debates, just to name a few. The metanarratives that we find in IEL are representative of the reaction of International Law to the introduction of variables that disturb the normal functioning of the system, which in its classical way is to rely heavily on the sources of International Law, with treaties being the most important one.

\section{ii. Empirical Manifestations of Metanarratives in IEL}

The visible and non-visible dimensions of imperial domination in IEL are manifest in the irradiating discourse of technology and progress as the only way for survival in the postmodern world. For that reason, the language of IEL adopts indirect and sophisticated content that indicates the attainment of noble goals such as increasing environmental security and eradicating hunger or poverty as part of the quest for a climate change governance, which shall be examined below.

First let us take a look at the security goal. To Buzan, the concept of security is very problematic because it presents elements that impede its investigation and recognition empirically. ${ }^{34}$ As a form of discourse, the objectification of security depends on the moral, ideological and normative markers in the international system at a certain point in history.

The end of the Cold War brought severe changes in these markers to a point in which inherent social transformations in the international system were necessary to incorporate a more comprehensive notion of international security that includes new threats and actors. ${ }^{35}$ According to Ullman, a new meaning of security is necessary:

A more useful (although certainly no conventional) definition might be: a threat to national security is an action or sequence of events that (1) threatens drastically and over a relatively brief span of time to degrade the quality of life for the inhabitants of a state, or (2) threatens significantly to narrow the range of policy choices available to the government of a state or to private, nongovernmental entities (persons, groups, corporations) within the state. ${ }^{36}$

Thus, the securitization of an issue in international politics means a deliberate political process that places a referential object (climate change, for instance) in a special position or urgency that an immediate response is required by the State, region or international society. As such, security ' $[\ldots]$ has to be staged as an existential threat to a referent object by a securitizing actor, [to generate] endorsement of emergency measures beyond the rules that would otherwise bind'. ${ }^{37}$ Presenting the issue as an existential threat provokes a generalized concern that justifies extreme measures followed by 'extrabudgetary reallocation of resources to combat it'. ${ }^{38}$

The process and discourse of securitization of climate change follows the rationale describes before, in which the existential threat is posed by developed countries. As stated by Bodansky:

\footnotetext{
34 Acharya, A and Buzan, B, "Conclusion: On the possibility of a non-Western IR theory in Asia" 7(3) Oxford Academic - International Relations of the Asia-Pacific (2007) 427, $<$ academic.oup.com/irap/article/7/3/427/758315> (accessed on 19 November 2017).

35 Mathews, JT, "Redefining Security" 68(2) Foreign Affairs (1989) 162; Ullman, RH, "Redefining Security" 8(1) International Security (1983) 129.

36 Ullman, Ibid, 133.

37 Buzan, B, Waever, O, and De Wilde, J, Security: A new Framework for Analysis/21 (Lynne Rienner Publishers 1998).

38 Ibid.
} 
North American heat wave and drought of the summer of 1988 gave an enormous popular boost to greenhouse warming proponents, particularly in the United States and Canada. By the end of 1988, global environmental issues were so prominent that Time magazine named endangered Earth "Planet of the Year." A conference organized by Canada in June 1988 in Toronto called for global emissions of CO2 to be reduced by 20 percent by the year 2005, the development of a global framework convention to protect the atmosphere, and establishment of a world atmosphere fund financed in part by a tax on fossil fuels. ${ }^{39}$

This leads to a more unstable scenario, which is the dislocation of a political issue to the security sphere that includes the military dimension. As such, Hartmann states:

This beating of the climate conflict drums has to be viewed in the context of larger orchestrations in U.S. national security policy. While development assistance and humanitarian aid have long been strategically deployed as an element of defense policy, in recent years the military has encroached much further into civilian territory. Observers are beginning to speak of an 'aid-military complex' —in 2005, the share of official U.S. development assistance dispersed by the Pentagon was 21.7 per cent, up from 5.6 per cent 3 years before. The State Department's role in both diplomacy and development has been severely weakened as a consequence, and disaster response is increasingly becoming the purview of the military. ${ }^{40}$

The spill-over of the reaction of developed countries soon reached the international system and institutions as it is impossible under a systemic approach to provide responses to climate change. This is what we see below in Figure 4:

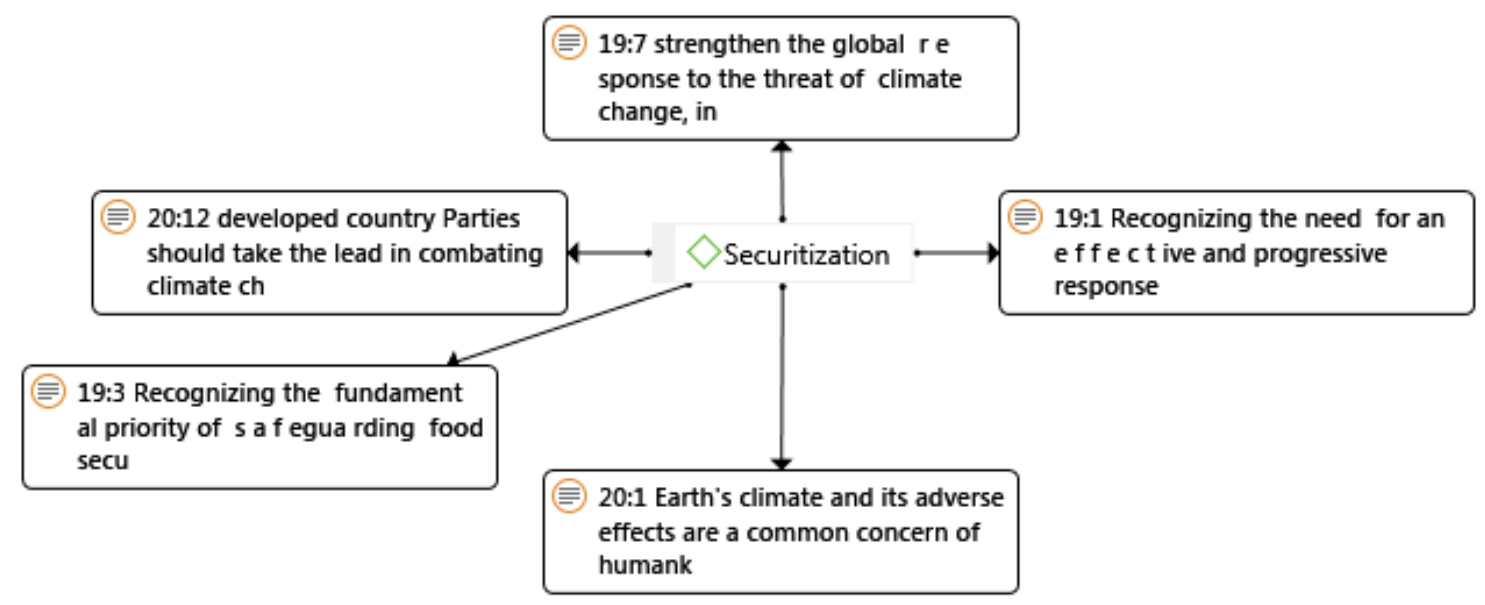

Figure 4 (Quotes from Agreements - the number 19 refers to the Paris Agreement and 20 the UNFCCC).

Therefore, the response to the existential threat that generates environmental insecurity is embedded in IEL in the form of language that developed countries should lead (20:12). Moreover, the need for an effective and progressive response (19:1) generates the

39 Bodansky, D, "The History of the Global Climate Change Regime" 23 International Relations and Global Climate Change (2001) 23.

40 Hartmann, B, "Rethinking climate refugees and climate conflict: Rhetoric, reality and the politics of policy discourse" 22(2) Journal of International Development (2010) 223. 
legitimation of any measure that needs to be taken to secure the 'normal' environmental security. ${ }^{41}$

The other form of imposing metanarratives is found in the current international food system. The current food system is grounded on monocultures for exportation. Thus, while declaring the need to increase output to eradicate hunger and poverty, the system generates local degradation of the environment and biodiversity, both important contributing causes to climate change.

The food crises that hit the world food system in 2006 and 2008 had devastating effects on developing countries, providing solid evidence for our argument. ${ }^{42}$ The crises have caused great social and political upheaval, especially in developing countries whose vulnerability in the food system is enormous. Protests and violence have been reported in many countries in the Global South, of which we can cite the tragic case in Haiti that had coined the term 'Clorox Hunger', which translates the excruciating sensation of hunger in the body as if the person had ingested bleach. ${ }^{43}$ Bello sums up this scenario:

Alarmed by massive global demand, countries like China and Argentina resorted to taxes or quotas on their rice and wheat exports to avert local shortages. Rice exports were simply banned in Cambodia, Egypt, India, Indonesia, and Vietnam. South-South solidarity crumbled in the crisis, a victim of collateral damage. ${ }^{44}$

The United Nation (UN) in the World Economic Situation and Prospects called the food crisis of 2008 a 'perfect storm', placing the financial crisis in 2007 as the protagonist of the food riots. According to the report:

41 See Græger, N., "Environmental Security?” 33(1) Journal of Peace Research (1996) 109.

42 Modern agriculture is producing more food per capita than ever before. At the same time, according to estimates from the Food and Agriculture Organization, approximately 795 million people are currently affected by hunger. An additional two billion people are suffering from micronutrient deficiencies, lacking key vitamins and minerals. In 2014, 1.9 billion people were overweight, of these 600 million were obese. Climate change will present an enormous new challenge to agriculture while the world population is predicted to increase to 9 billion by 2050. Whether clean water, fertile soils, forests, wetlands and other natural resources, as well as the biodiversity of the planet, will be available to future generations, in a condition that enables them to survive, will depend crucially on the way we produce our food and on our diets. Agricultural activities and the subsequent processing, storage, transport and disposal of its products are directly or indirectly responsible for almost $40 \%$ of human-induced greenhouse gas emissions. One third of the world's population obtains its livelihood from agriculture. Agriculture and food is by far the world's largest business and the measure of all forms of sustainable development. In Global Agriculture, About the IAASTD Report, <globalagriculture.org/reporttopics/about-the-iaastd-report.html> (accessed on 18 November 2017); Guo, S and Rojas, D, "The Global Food Crisis" 13(2) Yale Human Rights and Development Journal (2010), < digitalcommons.law.yale.edu/ yhrdlj/vol13/iss2/8 > (accessed on 19 November 2017).

43 Even before the acute food crisis, the U.S. President George W. Bush had alerted his nations to the need to secure food, 'It's important for our Nation to be able to grow foodstuffs to feed our people. Can you imagine a country that was unable to grow enough food to feed the people? It would be a nation that would be subject to international pressure. It would be a nation at risk. And so, when we're talking about American agriculture, we're really talking about a national security issue.' In The American Presidency Project, Remarks to the National Future Farmers of America Organization, July 272001 , <presidency.ucsb.edu/ws/index.php? pid=63838> (accessed on 18 November 2017); Jayaraman, S, "International Terrorism and Statelessness: Revoking the Citizenship of ISIL Foreign Fighters" 17(1) Chicago Journal of International Law (2016) 178, < chicagounbound.uchicago.edu/cjil/vol17/iss1/6/>, (accessed on 19 November 2017).

44 Bello, WG, The Food Wars (Verso 2009). 
Speculation in the actual, physical exchange of commodities certainly influenced prices as speculators bought and stored commodities, betting on price increases. Such positions have temporarily reduced the supply of goods and have no doubt affected price movements directly. The impact of speculation in futures markets (that is to say, where speculators do not physically trade any commodities) on price trends is much more difficult to determine, however. Futures trades are bets on buying or selling goods entitlements which are continuously rolled over. It is therefore not clear whether such trading does more to commodity prices other than increase their volatility. ${ }^{45}$

Thus, the food crisis is not related to a lack of sufficient food to feed the poor but rooted in development-oriented economic issues and the need to overcome the limits of the environment at all costs, that is, the maintenance of the current food system, which has already been proved to contain such serious structural failures. The International Assessment of Agricultural Knowledge, Science, and Technology for Development stated:

Underinvestment in developing country agriculture-including in local and regional market infrastructure, information and services - has weakened the smallscale farm sector in many countries. Trade liberalization that opened developing country markets to international competition too quickly or too extensively further undermined the rural sector and rural livelihoods. Many countries have been left with weakened national food production capacity, making them more vulnerable to international food price and supply volatility and reducing food security. ${ }^{46}$

The alternative to the current food system, and thus an agricultural model that could have a positive impact on climate change, is the food sovereignty model based on local farming. As it defies the mainstream perception of development, it is not very popular among international institutions. For instance, during the Uruguay Round in 1986, the Secretary of Agriculture John Block is quoted in Bello:

[...] the idea that developing countries should feed themselves is an anachronism from a bygone era. They could better ensure their food security by relying on US agricultural products, which are available, in most cases at lower cost.

The fallacy of this argument is that the prevailing food system is good for all. In fact: 'not only in the South but also in the North, farmers and others seek to escape the vagaries of capital by reproducing the peasant condition, working with nature from a limited resource base independent of market forces. ${ }^{47}$

Thus, the existing food system model grounded in the mantra 'increasing the food output $=$ hunger eradication' is misleading. There is a fundamental dissonance found in international institutions and the crude reality of the world. Although food production is growing, hunger is prevalent around the world, monocultures have been damaging local environment and biodiversity, and the transportation of large sums of food needs an

\footnotetext{
45 United Nations Development Policy and Analysis Division, World Economic Situation and Prospects (WESP) Report, <un.org/development/desa/dpad/document_gem/global-economic-monitoring-unit/ world-economic-situation-and-prospects-wesp-report/> (accessed on 18 November 2017).

46 Ibid.

47 Bello supra nt $44,86$.
} 
extensive and intensive transportation network. This produces negative impacts on climate change as it increases outputs of greenhouse gases by the high consumption rate of petroleum, fertilizers, intentional burnings to clean fields, etc. ${ }^{48}$

In conclusion, there are important indications of the existing metanarratives being used in IEL that carry out totalizing discourses and world views that are very damaging to minorities, and are thus viewed as obstacles to development. In this sense, the following part of this article promotes a dialectic encounter of the metanarratives with feminist theory.

\section{Feminist Theory as a Resistance Stance to Metanarratives in IEL}

The interjection of FT in the process of explaining and understanding the logic of institutions in dealing with climate change is necessary in analytical terms and as a form of reaction to the Kafkian nightmare that individuals are impotent when facing the anonymous power of institutions. It consists of a theoretical toolkit that helps non-state actors in dealing with what Anders calls 'the cognitive paralysis', which is self-evident due to the existing state institutions and the high complexity of climate change. ${ }^{49}$

Tickner categorizes FT as liberal, radical, socialist, psychoanalytic, postcolonial, and postmodern. ${ }^{50}$ The common traces among those strings of feminism are: 1 . explaining the causes for women's subordination or unjustified economic and social asymmetry in relation to men and 2. prescribing ways to end it. As put by Okin et al., feminism is the flag for those '[...] who believe that women should not be disadvantaged by their sex; women should be recognized as having human dignity equal with men and the opportunity to live as freely chosen lives as men. ${ }^{51}$

For this article, the string of FT adopted is the postcolonial one, as it intervenes in both feminist and postcolonialist dimensions due to their insufficient treatment of cultural, ethnic, and gender differences. According to Zuckerwise, '[...] postcolonial feminists are in a unique position to articulate the politics of lived reality in its theoretical and material forms', ${ }^{52}$ which provides a framework of analysis that goes beyond women's sexual subordination and victimhood to a more empowering intervention and the formation of critical knowledge that resonates with other classes of disadvantaged people. For that reason, searching for the missing concepts of hope, creativity, resilience, persistence, and solidarity in IEL results in an analysis of finding the trouble boundaries in IEL for the purpose of providing a more challenging account of its impacts and presenting a different story about its possibilities in the international system. ${ }^{53}$

Bringing the theoretical framework of FT, especially postcolonial feminism, to IEL provides a clear picture of the undesired structures of discrimination and domination

48 Shiva, V, Monoculturas Da Mente. Perspectivas Da Biodiversidade E Biotecnologia, 2003; Caron, R, Primavera silenciosa, (2015).

49 Anders, G, L'obsolescence de l'homme. Paris: Éd. de l'Encyclopédie des nuisance, Encyclopédie des nuisances (2002).

50 Tickner, JA, Gendering World Politics (Columbia University Press 2001).

51 The various strings of feminism are formed by the disagreement in relation to what constitutes the subordination to men and how to overcome it. For additional knowledge in the debate: McCann, C and Kim, SK, Feminist Theory Reader: Local and Global Perspectives (Routledge 2013).

52 For a deeper discussion on postcolonial feminism, see: Mohanty, CT, "Under Western Eyes: Feminist Scholarship and Colonial Discourses" 12(13) Jstor (1984) 333, <jstor.org/stable/302821? origin=crossref\&seq=1\#page_scan_tab_contents $>$, (accessed on 19 November 2017).

53 Robinson, M, International Law: Modern Feminist Approaches: With a Foreward by Mary Robinson (Hart Publishing 2005). 
in international institutions, which the discourse of IEL has sustained by metanarratives of objectivity, universality, and neutrality ${ }^{54}$ For Dianne Otto:

I conclude by highlighting the paradoxes of feminism engagement with international law and argue that the practices of critique and reform, and their productive tensions, are essential to resisting the law's colonization of feminist politics and keeping feminist imaginaries of a better world alive. It is in the interstices of hope and despair, conundrum and paradox, that feminists have the best chance of understanding how international law might yet be a means for promoting feminist change. ${ }^{55}$

For that matter, the issues arising from the encounter of FT with IEL might be two-fold. The most visible dimension is the lack of participation of women in international regimes due to national structures that prevent their presence. ${ }^{56}$ The lack of participation causes the less visible dimension, which is associated to the marginalization of issues/interests and/or the disrespect of women's conceptions and practices of the social reality connected to their nurturing and caring nature. ${ }^{57}$ In this sense:

We can see that female politicians are defined more by their deficits than their strengths. In addition to failing to possess the strengths associated with being women (e.g., sensitive or compassionate), female politicians [are seen to] lack leadership, competence, and masculine traits in comparison to male politicians. ${ }^{58}$

In addition, to reinforce the argument above, and advancing the debate of gender inequality in the climate change regime as perpetuator of imperial dominance, Sweetman citing Margareth Skutsch:

[...] expert in development co-operation, energy, and climate change, offers two arguments for including gender considerations in the process of climate-change policy development: the idea that such gender mainstreaming may increase the efficiency of the climate-change process; and the idea that if gender considerations are not included, progress towards gender equity may be threatened. In other words, the quality of policy making will remain unacceptably low, if the discourse

54 About metanarratives, see: Eagleton, T, The Illusions of Postmodernism (1st ed, Wiley-Blackwell 1996); Lyotard, JF and Jameson, F, The Postmodern Condition: A Report on Knowledge (1st ed, University of Minnesota Press 1984); Orford and Hoffmann, supra nt 32.

55 Orford and Hoffmann supra nt 32, 490.

56 Outshoorn, J and Kantola, J, Changing State Feminsim (Palgrave Macmillan 2007).

57 In a 2008 Pew Research Center survey of eight important leadership traits, women outperformed men on five and tie on two. Americans ranked women higher in honesty, intelligence, compassion, creativity, and outgoingness - by as much as 75 percent. And in the qualities of hard work and ambition, men and women tied, according to the survey. The only quality in which men scored higher than women is decisiveness, in which men and women were separated by a mere 11 percentage points. Yet when asked the single question if men or women make better leaders, the results seemed to contradict these other findings: a mere 6 percent of the 2,250 adults surveyed say women make better political leaders than men, with 21 percent favoring men and 69 percent saying the sexes are equal in this area, which explains the report's subtitle, 'A Paradox in Public Attitudes.' At Big Think, Cookson, J, Why Women Make Better Politicians, <bigthink.com/women-and-power/why-women-make-betterpoliticians>, (accessed on 18 November 2017). See also: Coleman, I, Paradise Beneath Her Feet: How Women Are Transforming the Middle East (Random House Trade Paperbacks 2013); Fiske, ST, Gilbert, DT and Lindzey, G, Handbook of Social Psychology (5th ed, Wiley 2010).

58 Baksh, R and Harcourt, W, The Oxford Handbook of Transnational Feminist Movements (Oxford University Press 2015), p 237. 
does not consider the gender issues, including relevant differences between women's and men's experience. ${ }^{59}$

\section{The Encounter of Imperial Language With FT Operative Concepts}

One of the persistent dimensions of imperialism is imbricated into the legal tradition. In this sense, Wolkmer presents:

It is not too important to remember that in Latin America both the legal culture imposed by the metropolises throughout the colonial period and the legal institutions formed after the independence process (courts, codifications and constitutions) derive from the European legal tradition, In the private sphere, by the classical sources of Roman, Germanic and canonical rights. Similarly, in the formation of the legal culture and the post-independence constitutional process, account must be taken of the inheritance of bourgeois political charters and of the illuminist and liberal principles inherent in the declarations of rights as well as of the new capitalist modernity, free market, based on false tolerance and on the liberal-individualist profile (Translated by the author). ${ }^{60}$

This tension is captured by Débora Ferrazzo in the essay $O$ Novo Constitucionalismo $e$ Dialética da Descolonização by pointing out the premises of what she called the Eurocentric theorization of legal science inherited by the countries of the Third World. She states that:

The hierarchical structure of norms is Eurocentric theorization of legal science. Consolidated by Hans Kelsen in his Pure Theory of Law, the proposal to submit rules of social regulation to other norms that confer efficacy to the reach of a fundamental norm spread throughout the West and much of the East. This means that all the expressions of law of different societies must be validated, identified with the law, in order to be able to take effect and be enforceable between members of these societies. In short, it is only right if becomes positive law, validated by a higher norm, that in the legal culture homogenized in the world, would be the Constitution Translated by the author) ${ }^{61}$

In this same vein, according to Boaventura de Sousa Santos resisting this paradigm of domination requires to overcome what he calls the abyssal line:

It consists of a system of visible and invisible distinctions, the latter of which are based on the former. Invisible distinctions are established by radical lines dividing social reality into two distinct universes: the 'this side of the line' and the 'the other side of the line.' The division is such that 'the other side of the line' disappears as reality, becomes non-existent and even produced as non-existent. Inexistence means not existing in any way of being relevant or understandable. Everything that is produced as non-existent is radically excluded because it remains outside the universe which the very conception of inclusion considers as the 'other.' The fundamental characteristic of abyssal thinking is the impossibility

59 Sweetman, C, Climate Change and Gender Justice (Practical Action Publishing 2009), 156.

60 Wolkmer, AC, Constitucionalismo Latino-Americano - Tendências Contemporâneas (Jurua Editora 2013), 2223.

61 Wolkmer, AC, Pluralismo Jurídico. Fundamentos de Uma Nova Cultura no Direito (Edição 2015), 32. 
of co-presence on both sides of the line. The universe 'on this side of the line' only prevails insofar as it exhausts the field of relevant reality: beyond the line there is only non-existence, invisibility and non-dialectical absence (translated by the author). ${ }^{62}$

Therefore, the abyssal line of thinking requires homogenizing politics, law, values, and democracy, just to mention a few, so a non-existence and invisibility exists. This implicates in the prevalence of reductionisms contained in the metanarratives that no longer respond to the challenges in the world as of today. ${ }^{63}$ On the other hand, facing these metanarratives such as International Law requires a critical thinking position that provides the tools to identify forms of domination, especially the subtle ones.

In Figures 5 and 6 we observe the dialectics of IEL and FT grounded in the Agreements regulating the climate change regime. The concepts or codes representing the metanarratives of IEL (in blue) are 'development', 'sustainable development', and 'universality' that disregard the stages of modernity in which the North and South are historically located today. ${ }^{64}$

The codes representing FT (highlighted in yellow) are ' solidarity', ' $\sim$ resilience', and ' $\sim$ creativity', with the ' $\sim$ ' sign being added to reference the contradiction of the core concepts of FT with the metanarratives within the Agreements.

In addition, the analysis of the Agreements showed the emergence of another contradictory concept that challenges the metanarratives of IEL - climate justice (in green). According to Heyward \& Roser, the concept of climate justice is associated with the following debate: ${ }^{65}$

For most people, the main reason for limiting greenhouse gas (GHG) emissions is not the impacts on the environment per se but the resulting effects of climate change upon humans. Of particular concern is that climate change is expected to have disproportionate effects on regions where severe poverty is already widespread. At present, more than 2.2 billion people are vulnerable to multidimensional poverty and 1.2 billion people live on less than $\$ 1.25$ per day. ${ }^{66}$ Climate change stands to make the very poorest in the world even poorer. Indeed, it is 'one of the most critical challenges to the global development agenda' ${ }^{67}$ Although the poorest are potentially most affected by climatic impacts, they are least involved in creating the problem. Historically speaking, it is people in developed countries who have emitted the most. ${ }^{68}$ Since climate change is primarily caused by some parts of humanity whilst the effects of climate change will be largely suffered by others, it is a matter of justice. Indeed, most theorists who write about climate change do so in the language of justice. ${ }^{69}$

62 Santos B and Meneses, MP, Epistemologias Do Sul (Almedina 2010).

63 Lyotard and Jameson, supra nt 54.

64 Ibid.

65 Heyward, C and Roser, D, Climate Justice in a Non-Ideal World (Oxford University Press 2016), 2.

66 United Nations Development Program, REPORT : Sustaining Human Progress: Reducing Vulnerabilities and Building Resilience, 2014, at <hdr.undp.org/sites/default/files/hdr14-report-en-1.pdf> (accessed on 19 November 2017), 19.

67 Ibid, 12.

68 Den Elzen, MGJ and Hof AF and Roelfsema, M, "Analysing the greenhouse gas emission reductions of the mitigation action plans by non-Annex I countries by 2020" (56) Energy Policy (2013) 633.

69 See, for example, Page 2006; Vanderheiden 2008; Gardiner 2011; McKinnon 2012; Cripps 2012; Caney 2014; Shue 2014. 


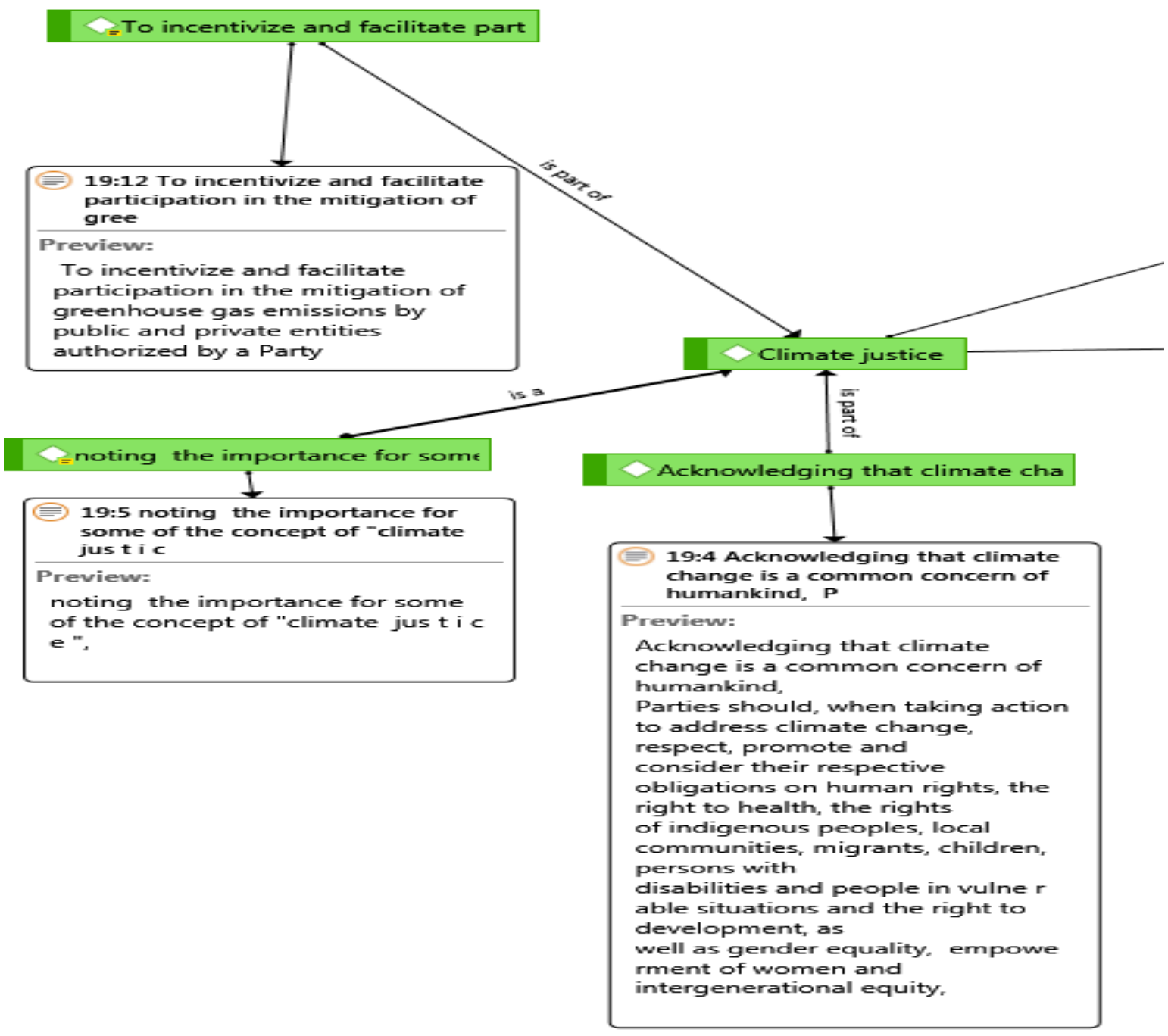




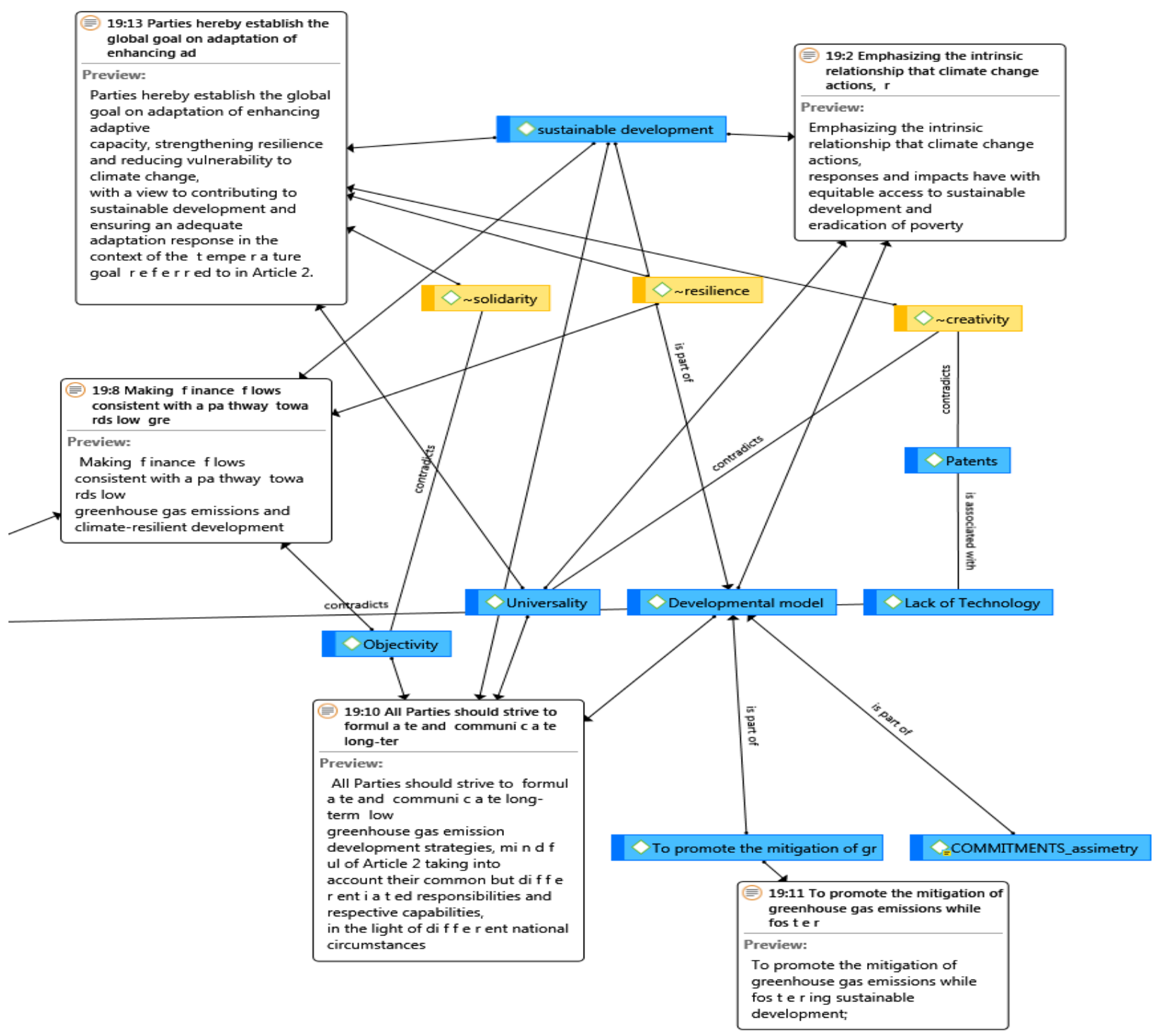

Figure 5 and 6 (Relations between metanarratives and FT concepts, and excerpts of the Agreements as empirical evidences)

\section{i. The Logic of Metanarratives: Sustainable Development to Whom?}

The language in the Agreements presents a strong and central presence of metanarratives such as development, economic, sustainable, etc. and a peripheral or marginal location for ideational factors such as hunger, socially, vulnerability, resilience, etc. Figure 8 below provides empirical evidence of the less visible dimension of the domination and violence against women, and other misrepresented minorities in the international system dominated by what Déborah Danowski and Eduardo Viveiros de Castro call the superdeveloped countries, which are eager to continue the process of super-development. ${ }^{70}$ Using the same set of treaties as explained before, the 'word cloud' below shows the centrality of terms such as 'development' and 'economic', while 'beneficial' and

70 Danowski, Déborah and Castro, EV, The Ends of the World (1st ed, Polity 2016). 
'poverty', for instance, are peripheral to institutions dealing with the climate change debate.

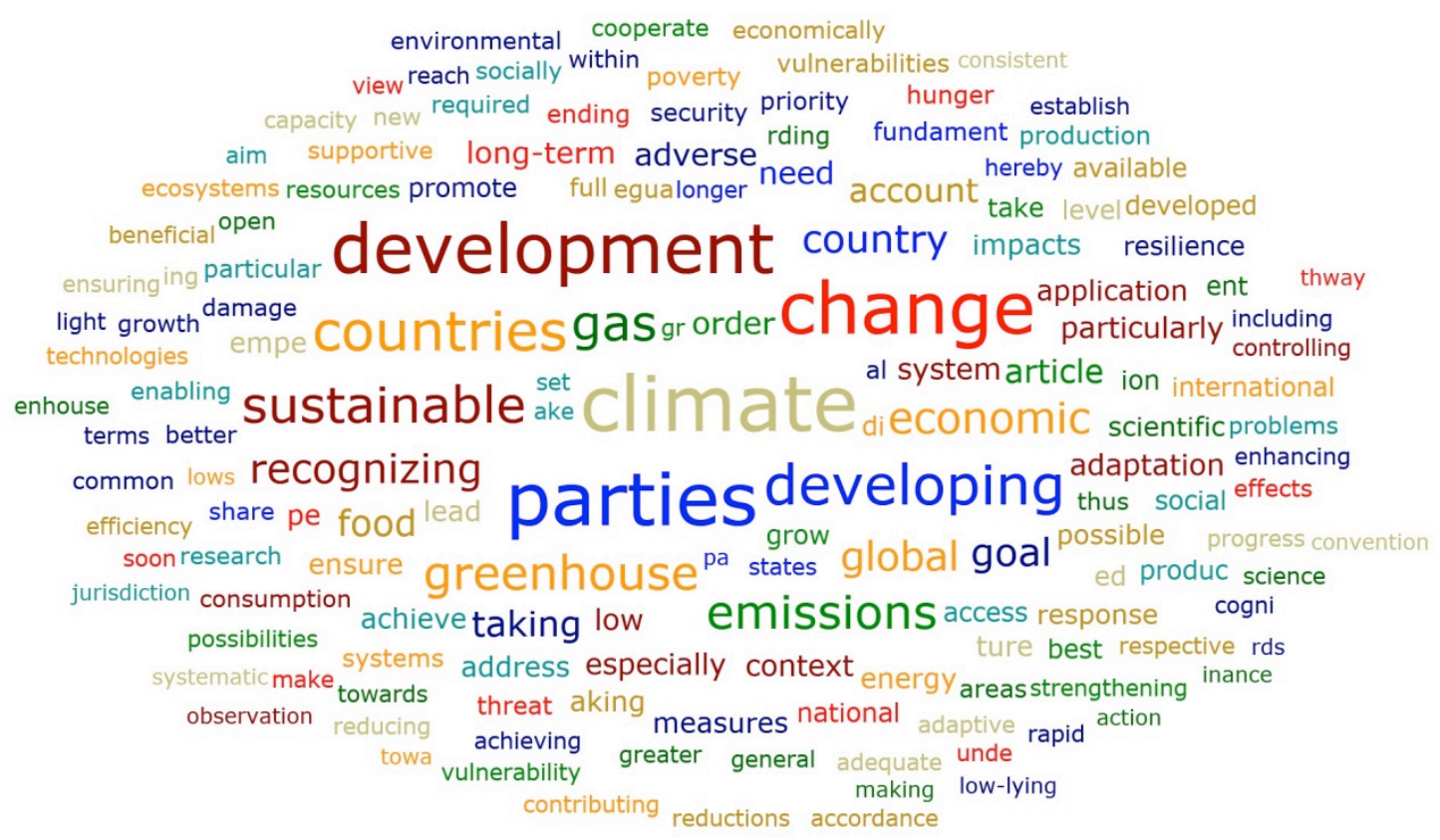

Figure 7

One of the devices found in IEL that reflects the argument above is the principle of sustainable development that appears in IEL as 'cultural performance', which for Alexander is '[...] the social process by which actors, individually or in concert, display for others the meaning of their social situation. ${ }^{, 71}$ Let us understand the dynamics played by this metanarrative as the normal or desired functioning of the climate change regime.

Initially, we need to note that there are multiple views and perceptions on how to achieve sustainable development. The normal concept as generally adopted in IEL is described by Sands, Peel, Fabra, \& MacKenzie:

The Brundtland Report defined sustainable development as 'development that meets the needs of the present without compromising the ability of future generations to meet their own needs'. It contains two key concepts: the concept of needs, in particular the essential needs of the present generation, and the idea of limits imposed by the state of technology and social organisation on the environment's ability to meet present and future needs. ${ }^{72}$

As observed, the normal concept lacks two important historical and material dimensions - how development is perceived by Third-World countries vis-à-vis environmental protection and use of natural resources and to what extent developed countries that plundered the nature to achieve their status possess legitimation to dictate how the scale between environmental protection and development will work towards one or the other end (and the pervasive unwillingness to transfer technology to help increase environmental protection).

71 Alexander, JC, Performance and Power (Polity 2011), 26.

72 Sands, PP et al, Principles of International Environmental Law (Cambridge University Press 2012), 9. 
Fredrick Oduol Oduor presents an important implication of the normalization of the sustainable development principle:

Sustainable development continues to evolve into a fundamental concept in international law. It is because of sustainable development that the South accepted to be part of environmental discourse. As a result, their view changed from contestation to participation as clearly evidenced in Johannesburg. The Johannesburg forum expanded on the concept of sustainable development and the south embraced it because it recognized their needs. Unfortunately, the schism between the two blocks reinvented itself into the understanding and implementation of the concept. O'Riordan opined that sustainable development is 'becoming accepted as the mediating term that bridges the gap between developers and environmentalists. Its beguiling simplicity and apparently self-evident meaning have obscured its inherent ambiguity. ${ }^{73}$

By carving the concept of sustainable development, and including it in the legal framework of IEL, super-developed countries underscore the goal of imposing their political agenda. As posed by Skolimowski:

The implications of performance theory for understanding power are clear. According to conventional conceptions, whether Weberian or Marxist, power is institutional- structural. It is the ability to make somebody do something whether they like it or not. Coercion, or the ability to threaten it, is critical from such a perspective, which leads to the centrality of such ideas as control over means of production or monopolization of the means of violence. From this point of view, you don't need ideas to exercise power; you just need resources and capacities. ${ }^{74}$

In that sense, it is worthwhile noting a similar political phenomenon involving development that illustrates the potential outcome for adopting sustainable development as proposed by IEL. The need and desire for development of Latin American countries received heavy attention after the end of the Second World War, mainly due to what has been known as the Trumann Doctrine, in which the motto is Producir más es la clave para la paz y la prosperidad. ${ }^{75}$ Development had become a fundamental problem to the underdeveloped countries that submitted themselves to interventionist practices as 'the' only way to achieve development. ${ }^{76}$ In conclusion, Galeano states how the metanarrative of development works:

In the rigid framework of a global capitalism integrated around the big U.S. corporations, the industrialization of Latin America has increasingly less to do with progress and national liberation. The talisman was robbed of its power in the decisive defeats of the past century, when ports triumphed over interiors and free

73 At Social Science Research Network, Oduor, FO, Developing Countries, Environmental Challenges, Politics and Human Rights: Another Conundrum in the Quest to Deconstruct the 'Right to Poverty', 9 September 2010, <papers.ssrn.com/sol3/papers.cfm?abstract_id=1674231> (accessed on 19 November 2017).

74 Skolimowski, "H, Power: Myth and Reality" 9(1) Alternatives (1983) 25, <journals.sagepub.com/doi/abs/10.1177/030437548300900102> (accessed on 19 November 2017), p. 4.

75 To produce more is the key for peace and prosperity (Translated by the Author); Escobar, A, La Invencion del Tercer Mundo (Norma 2000), 19.

76 See also Silva, GB, Estado De Derecho Y Globalizacion. El PapeL, ILSA - Instituto Latinoamericano de Servicios Lega (2009). 
trade crushed new-born national industries. Arid, the twentieth century produced no bourgeoisie strong and creative enough to shoulder the task and follow it through to its end. Every effort weakened the goal. What happened to Latin America's industrial bourgeoisie was what happens to dwarfs: it became decrepit without having grown. Our bourgeois of today are agents and functionaries of prepotent foreign corporations. Truth compels us to admit that they never did anything to deserve a better fate. ${ }^{77}$

The use of language devices international institutions put forward to justify the status quo of domination as an imperial project in the climate change regime is so surmountable that they are virtually impossible to examine in this paper, however, for the sake of the argument we present one additional example. IEL is prone to provide bad empirical evidence of the standard practice of the developed countries such as Bophal (India) ${ }^{78}$ and Mariana (Brazil). ${ }^{79}$ The standard practice is described by Agarwal \& Narain:

The fate of the Third World in this garbage business is now clear. As far as the West is concerned it can live to fix its carbon or plant cheap trees or dispose its toxic wastes as has been the case in the past. A World Bank staff paper has even given this garbage business a high sounding new name; 'intergenerational compensation project'. Whose generation are they talking about? ${ }^{80}$

\section{Conclusion}

The emergence of IEL is directly connected to the growing anthropogenic activities and the complexity encountered in dealing with natural resources with no physical limitation. The international institutional responses to environmental challenges, although necessary due to the systemic nature of the problem, are subordinated to tenets grounded in International Law long before the environment became a problem.

In this sense, the climate change regime has been formed under the prevalent logic of imperialistic domination, which as theorized and observed in this article presents both visible and less visible dimensions of domination and violence that exclude minorities usually located in the Global South, and therefore, more exposed to the vulnerabilities of the international system and protection of International Law.

The application of the socio-legal methodology in which text, subtext and context of IEL are examined allowed to expose some of the metanarratives and confronting them with FT. To that end, the study presents evidence of the existing disconnection in the political agenda of developed and Third World countries, which results in a body of law that (1) increases the vulnerability and inequality, (2) does not allocate properly the responsibility, (3) promotes super-development of the already developed countries and (4) imposes externalities only to Global South countries.

The findings in this study represent an initial effort to build a research agenda that confronts IEL to other world views and perceptions, which at the end is expected to

77 Galeano, E, Open Veins of Latin America: Five Centuries of the Pillage of a Continent (Monthly Review Press; Anniversary Edition 1997), 207.

78 Oduor, supra nt 73.

79 The Guardian, Phillips, D, Brazil's Mining Tragedy: Was it a Preventable Disaster? 25 November 2015, at $<$ theguardian.com/sustainable-business/2015/nov/25/brazils-mining-tragedy-dam-preventabledisaster-samarco-vale-bhp-billiton> (accessed on November 19 2017).

80 Agarwal, A, and Narain, S, Global Warming in an Unequal World: A Case of Environmental Colonialism, Centre for Science and Environment (1991), 17. 
190 GroJIL 5(2) (2017), 168-190

present strong empirical evidence that supports the argument that metanarratives as currently found in IEL do not provide enough reach to emancipate or protect minorities, increase inclusion, protect the environment and so forth. This paper also represents a provocative piece to generate enough incentives to international lawyers to further pursue applying critical approaches to specific international regimes or institutions.

www.grojil.org 